\title{
Utilization of the Quality Assurance Handbook in Secondary School Supervision of Instruction in Enugu State, Nigeria
}

\author{
Chidobi, R. U. ${ }^{1} \&$ Eze Thecla. A. Y. ${ }^{1, *}$ \\ ${ }^{1}$ Department of Educational Management, Enugu State University of Science \& Technology, Enugu (ESUT), Nigeria \\ *Correspondence: Department of Educational Management, Enugu State University of Science \& Technology, \\ Enugu (ESUT), Nigeria. E-mail: chidobiroseline123@yahoo.com; thecla_yvonne99@yahoo.com
}

Received: May 22, 2016

Accepted: June 15, 2016 Online Published: August 12, 2016

doi:10.5430/wje.v6n4p30

URL: http://dx.doi.org/10.5430/wje.v6n4p30

\begin{abstract}
The purpose of this study is to investigate the extent of utilization of Quality Assurance Handbook in the supervision of instruction in secondary schools. Descriptive survey design was employed. The quantitative data were collected through an 18-item questionnaire titled, "Extent of Utilization of Quality Assurance Handbook in Secondary School Supervision of Instruction and Hindrance" (EUQAHSSSIH). This was administered to 210 supervisors made up of external and internal supervisors. Data were analyzed using mean and standard deviation for research questions and t-test statistics for the two hypotheses. Findings of the study revealed among others that both external and internal supervisors do not make adequate utilization of the Quality Assurance Handbook, in the supervision of instruction of secondary schools in Enugu State. It was also revealed that some factors which include unawareness of the supervisors about the existence of the Handbook contributed to its non-utilization. Based on the above some recommendations were made: such as making the Handbook available to principal in the schools.
\end{abstract}

Keywords: utilization; quality assurance handbook; supervision of instruction; secondary school.

\section{Introduction}

Education is an important tool for human and national development. It is a key to national development. The education given to citizens of a country especially at the secondary school level must be of good quality to inculcate in them the necessary skills for self development and survival. Quality education is a necessity in order to build responsible citizens who can drive the economy of the nation and compete favorably in the knowledge based world of today.

Quality assurance, in the words of Duff and Hussey (2000), is a process of exhibiting excellence. Also Oxford Advanced Learner's Dictionary (6edition) states that quality assurance has to do with the practice of managing the production of goods and services to ensure high standard. Campbell and Rozsnyai (2002), opined that quality assurance is an all embracing effect whereby all policies and actions through which quality of education is developed and maintained. Melia (1994) in Ekwukoma (2016) summed up quality as standard. At the same time Woodhouse (1999), opined that quality assurance deals with all the policies, attitudes, actions and procedures used to ensure that the quality of output is achieved at the educational sector.

Quality assurance is to ensure that the product or services rendered are in perfect order, even beyond the expectation of the recipient. Especially as it concerns the supervision of instruction which is the main thing that leads to the achievement of educational goals. Ukwungwu (2008) posited that quality assurance is used to express "fitness of purpose". He further stated that quality in education bothers on effectiveness and efficiency of the school administration, teaching and learning. The quality of teaching and learning can only be assured through the supervision of instruction. In the secondary education, it has to do with all those qualities that lead to the successful and measurable students' outcome. This has to do with the supervision of teaching and learning.

The quality of education given in schools should be of great concern to all stakeholders. This becomes more worrisome with the declining performance of students in both the West African School Certificate and the Nationals Exanimation Council Examinations. The continued decline in the number of credit passed especially in core subjects 
like English Language and Mathematics seem to constantly point to the issue of quality of education received. There is the need for quality assurance in the secondary education. This is because at this level, those with a large repertoire of skills as well as an optimum capacity for learning go ahead to achieve lifetime uninterrupted economic fulfilment. While as those that are poorly educated become dropouts.

The quest for quality is a global issue in all works especially as it concerns educational system, which is in the recent time the supplier of manpower for all other institutions of the society. This is why the Federal Ministry of Education produced a document named: Quality Assurance Instrument for Basic and Secondary Education in Nigeria.

Secondary education in Nigeria comprises the upper basic and post basic education. Secondary education helps to sustain economic development by preparing students for the world of work. The quality of education at this level is important because it affects the trainability of youths and has implications for the relevance of education. It is at this level that objectives of secondary education are supposed to be diversified curriculum to cater for the differences of talents disposition, opportunities and future roles.

In order to ensure and maintain quality in education at the secondary school level, supervision and inspection of schools are carried out periodically. Supervision in the words of Bernard and Goodyear as cited by Adu, Akinloye and Olaoye (2014) is an intervention that is provided by a senior member of a profession to a junior member or members of that same profession. Supervision is supposed to be evaluative, and should enhance the professional functioning of the junior members. The main purpose of supervision is to improve teaching and learning ensuring that high standards are maintained in the delivery of instruction. A supervisor according to Hazi in Ekundayo, Oyerinde and Kolawole (2013) can be described as any certified individual assigned with the responsibility for the direction and guidance of the work of teaching staff members. The supervisor is an officer, most often from the Ministry of Education, who comes periodically to assess the way the school is administered, with emphasis on what the teachers teach or has taught the students. He ascertains whether what has been taught is in line with the syllabus. Supervision of schools should aim primarily at enhancing educational quality. External supervisors are supervisors outside the school - supervisors as the formally designated officials from the inspectorate division of the Ministry of Education and the various Area or Zonal Education Offices and Post Primary School Management Board. They interact with the teachers in the classes to assess to what extent the curriculum has been covered. The delivery method and the depth of the subject matter and assess the impact of the educational programme.

On the other hand, the external evaluators should arrange to do at least one joint observation with the head teacher or other senior teaching staff. There should be a brief and feedback to the head teachers on strengths and weakness and areas that need development.

\subsection{Role of Internal and External School Supervisors}

According to Ayodele (2002) in Kotirde and Yunos (2014) there are two categories of supervisors: internal and external supervisors. Internal supervisors are those within the school - principals, vice principals and heads of departments. As internal supervisors, these officers help to make sure that the educational activities are in tandem with the goals of education. They ensure that teachers teach what the curriculum specifies. They guide and more over encourage teachers. These officers as instructional leaders supervise classroom instruction, staff development, and curriculum development (Base and Blasé in Wanzare (2013).

The supervision is structured and evaluated taking account of

- Outcomes for learners

- The quality of provision and

- The impact of leadership and management.

A. In the outcome for learners, their academic achievements, personal skills and participation:

- How well learner make progress; and

- The standard acquired by learners.

- The extent of learners' spiritual, moral, social and cultural development.

- The extent to which learners know how to live healthy, fit and safe lives;

- How well learners enjoy their education;

- Learners behavior

- Attendance; 
- The extent to which learners make positive contribution to the school and wider community; and

- How well learners develop workplace and other skills that will contribute to their economic well being.

B. In the quality of teaching and learning, the extent to which learners acquire new knowledge and skills in their work, develop ideas and understanding.

- Show engagement, application and concentration and are productive;

- Develop skills and capacity to work independently and collaboratively

- The extent to which the school provides a broad range of worthwhile curricular opportunities that care for the interest, attitudes and particular needs of learners.

- How well the school ensures learners care, welfare, health and safety.

- How the school seeks to involve learners in its work and development.

- The extent to which the environment is conducive for effective learning.

C. How effective the school utilizes human and material resources to improve learners' outcome.

Studies by Kotirde and Yunos (2014) show that the process of supervision is becoming a serious problem that is yet to be properly addressed in Nigerian secondary schools. The need for adequate supervision is essential especially as Arong and Ogbadu (2010) revealed that the lack of adequate school supervision and inspection is a major cause of declining quality in education in Nigeria.

There is a world wide shift in the way supervision of school is carried out. The new concept of quality assurance has replaced the old method of supervision. Quality assurance according to the ESS Glossary (2010) is an organization guarantee that the product or services it offers meets the accepted quality standards.

Quality in the view of Anton and Naido (2014) is a multi-dimensional concept composed of three interrelated dimensions; the quality of the human and material resources available (inputs), the quality of the management and teaching/learning processes taking place (process) and the quality of the results (outputs and outcomes).

According to the Federal Ministry of Education (2010), education quality assurance in Nigeria is a paradigm shift from the former practice of school supervision and inspection to a monitoring and evaluating process that provides a new operative mode of evaluation. Evaluation processes and practices are now carried out according to set standards that bring about improvement in teaching and learning. Going further, it states that the process combines critical self assessment with independent external assessment. It is more cooperative and less inquisitorial than traditional ways of inspecting schools.

The Education Quality Assurance Handbook for Nigeria (2010) revised edition of the Federal Ministry of Education, Inspectorate Division is a comprehensive document which contains information on evaluation schedule, code of conduct for inspectors, quality assurance process for accreditation and arrangements for ensuring quality assurance of evaluators. The use of the handbook ensures that high quality education is provided for every child through collaboration with other stakeholders. In this way improvement in the quality of educational provision and outcomes is done by:

- $\quad$ Supporting and validating each schools own self evaluation.

- Undertaking quality assurance (QA) external evaluation of schools on a regular basis

- Providing regular support and challenge to schools (FME p.3)

- The instrument is to assist external evaluators and also leaders in the school, to help them evaluate the quality of education, it's impact on learners and the effectiveness of leadership and management. Guides;

- Planning external evaluation

- Gathering first-hand evidence in school

- Reaching judgement about the school's effectiveness, and

- Drafting a summary report of the main findings.

At the same time, there are guides to ensure that the code of conduct, the objectivity and security of evidence and quality of reports are maintained.

\subsection{The Role of the Quality Assurance Handbook as it Concerns Supervision of Instruction}

- Contribute to the school improvement 
- And contributed positively to learners' experience and achievement.

Although, the provision of this handbook to school boards and principals of schools for use is not encouraging, because the handbooks are distributed to different states of Nigeria yet the benefit of utilizing the handbook is immeasurable in the improvement of quality in schools.

\subsection{Challenges Hindering the use of Quality Assurance Handbook by the Supervisors}

Abebe (2014) opined that one of the things that causes hindrance, the handbook, might not be available in the school, for the supervisors to use. At the same time, both external supervisors and principals do not have adequate training programme on how to use the Quality Assurance Handbook for supervision of instruction.

Supervisors are faced with the absence of materials. This is a major problem which hinders their assignment in line with the above, Apebende (2013) succinctly stated that problems of supervision include no vehicle for transportation and non provision of supervisory materials to the supervisors. In support of the above Wanzare (2012) reiterated that the problem frustrating practices of instructional supervision were lack of resources, lack of consistency. The needed resources are not provided by the government and stakeholders of education. In addition, Ndu, Akinloye and Olaoye (2014) opined that financial constraints such as inadequate funding either on the part of government or concerned ministry hinders effective supervision of instruction.

\subsection{Statement of the Problem}

Education being an important instrument for national and economic development must be delivered to create value in the citizens. This can be done by ensuring that quality is maintained in its delivery. Sadly, the continuous decline in the performance of the outputs raises issues of quality. The government has established quality assurance policy and gone a step further to publish the Quality Assurance Handbook to be used by trained quality assurance officers. The problem of this study is to ascertain the utilization of the Quality Assurance Handbook for the supervision of schools, and challenges militating against the usage in secondary schools in Enugu State, Nigeria.

\subsection{Purpose of the Study}

The study investigated the utilization of the Quality Assurance Handbook for supervision of instruction in secondary schools in Enugu State.

1. Specifically, to identify the extent of utilization of the Quality Assurance Handbook by supervisors of instruction in secondary schools.

2. To examine the problem hindering the utilization of Quality Assurance Handbook for supervision of instruction.

\subsection{Research Questions}

1. To what extent do supervisors utilize the Quality Assurance Handbook in the supervision of instruction in secondary school in Enugu State?

2. What are the problems hindering the utilization of Quality Assurance Handbook for supervision of instruction?

\subsection{Hypotheses}

1. There is no significant difference in the mean response of internal and external supervisors on the extent of utilization of Quality Assurance Handbook during supervision of instruction in Enugu State secondary schools.

2. The difference between the mean response of internal and external supervisors on the problems associated with the utilization of Quality Assurance Handbook is not statistically significant.

\section{Method}

Descriptive survey design was adopted for the study. The study was carried out in Enugu State Public Secondary Schools. Enugu State is made up of six Educational Zones. The population of the study consists of all the principals and supervisors of Post Primary Schools Management Board(PPSMB) and Ministry of Education. The researchers used proportionate random sampling techniques of $50 \%$ to select 157 principals out of the population 314 principals and 63 out of 126 external supervisors. Therefore, the sample size for the study was 220 .

The instrument for the data collection was an 18-item researchers structured questionnaire titled, "Extent of Utilization of Quality Assurance Handbook in Supervision of Instruction and Hindrance" (EUQAHSSSIH). Two 
experts in Educational Management and one from Measurement and Evaluation Validated the Instrument. All corrections given were reflected in the final copy. To determine the reliability co-efficient of the instrument for cluster $\mathrm{A}=0.77$ and cluster $\mathrm{B}=0.79$ respectively and 0.78 for overall reliability index were obtained using Cronbach Alpha Method. This was high enough for the study. The instrument was a modified 4-point scale ranging from Very High Extent (VHE) - 4 points to Very Low Extent (VLE) - 1 point. For research question one and strongly agreed (SA) -4 points to strongly disagreed -1 point for the research question 2 . This instrument was administered with the help of two research assistants.

Out of 220 copies of the questionnaires distributed 210 copies were retrieved, (60 external supervisions and 150 principals). Thereby giving 210 return rate and 95 percent. Mean (X்) and standard deviation (SD) were used to collate the scores that answered the research questions while t-test was used to test the null hypotheses. For decision making, 2.50 was used as a benchmark, any item with a score of 2.50 and above was regarded as agreed while those scores less than 2.50 were disagreed. For the hypotheses, if the $t$-calculated is greater than or equal to t-critical, the null hypothesis is rejected while if less the null hypothesis is not rejected.

\section{Results}

Table 1. Mean Rating of the Respondents on the Extent of Utilization of Quality Assurance Guideline or Handbook in the Supervision of Instruction

\begin{tabular}{|c|c|c|c|c|c|c|c|c|}
\hline $\mathbf{S} / \mathbf{N}$ & Items & Exte & al sup & irvis & 60 & Princ & pals 15 & \\
\hline & To what extent do supervisors: & $\dot{\mathrm{X}}$ & $\mathrm{SD}$ & 60 & $\mathrm{RM}$ & $\dot{\mathrm{X}}$ & SD & \\
\hline 1 & $\begin{array}{l}\text { Ensure that quality is maintained in the } \\
\text { delivery of lesson. }\end{array}$ & 2.43 & 1.31 & & LE & 2.02 & 1.03 & LE \\
\hline 2 & $\begin{array}{l}\text { Use quality assurance handbook to ensure } \\
\text { high quality of education is provided for every } \\
\text { child }\end{array}$ & 2.87 & 0.95 & & $\mathrm{HE}$ & 2.77 & 0.99 & $\mathrm{HE}$ \\
\hline 3 & $\begin{array}{l}\text { Supervising and validating each schools own } \\
\text { self-evaluation. }\end{array}$ & 2.48 & 0.08 & & LE & 2.47 & 1.29 & LE \\
\hline 4 & $\begin{array}{l}\text { Undertaking quality assurance (QA) external } \\
\text { evaluation of schools on a regular basis. }\end{array}$ & 2.38 & 1.24 & & LE & 2.27 & 1.12 & LE \\
\hline 5 & $\begin{array}{l}\text { Providing regular support and answer to } \\
\text { challenges to school. }\end{array}$ & 2.35 & 1.30 & & LE & 2.37 & 1.14 & LE \\
\hline 6 & $\begin{array}{l}\text { Do they use comprehensive document which } \\
\text { contain information on evaluation schedule? }\end{array}$ & 2.35 & 0.99 & & LE & 2.17 & 1.05 & LE \\
\hline 7 & $\begin{array}{l}\text { Conduct of inspectors, quality assurance } \\
\text { process for accreditation and arrangement to } \\
\text { ensure high quality of the evaluation. }\end{array}$ & 2.45 & 1.06 & & LE & 1.97 & 0.89 & LE \\
\hline 8 & $\begin{array}{l}\text { The principal combining } \\
\text { self-assessment with independent } \\
\text { assessment. }\end{array}$ & 2.34 & 1.13 & & LE & 2.58 & 1.20 & $\mathrm{HE}$ \\
\hline 9 & $\begin{array}{l}\text { The use of monitoring and evaluation process } \\
\text { that provides a new operative mode of } \\
\text { evaluation. }\end{array}$ & 2,43 & 0.89 & & $\mathrm{LE}$ & 2.43 & 1.01 & LE \\
\hline 10 & $\begin{array}{l}\text { Using a set standard that bring about } \\
\text { improvement in teaching and learning. }\end{array}$ & 2.63 & 1.18 & & HE & 2.25 & 0.10 & LE \\
\hline
\end{tabular}

Summary of result table 1 revealed that almost all the items including the grand mean 2.48 and 2.39 for external and internal supervisors respectively agreed to a high extent that the Quality Assurance Handbook was not adequately utilized during supervision of instruction in Enugu State Secondary Schools. This is because they were below the benchmark of 2.50 . 
Table 2. Mean Rating of the Responses on the Factors That Hinder the Use of Quality Assurance Handbook Effectively by Supervisors

\begin{tabular}{|c|c|c|c|c|c|c|c|c|}
\hline \multirow[t]{2}{*}{$\mathbf{S} / \mathbf{N}$} & \multirow[t]{2}{*}{ Items } & \multicolumn{4}{|c|}{ External supervisors 60} & \multicolumn{3}{|c|}{ Principals 150} \\
\hline & & $\dot{\mathrm{X}}$ & SD & $\mathrm{N}$ & RM & $\dot{\mathrm{X}}$ & SD & $\mathrm{N}$ \\
\hline 11 & None availability of the handbook to supervisors. & 2.68 & 0.89 & & A & 2.95 & 1.03 & \\
\hline 12 & $\begin{array}{l}\text { Unawareness of what is in the quality assurance } \\
\text { handbook by the supervisors. }\end{array}$ & 3.15 & 0.64 & & $\mathrm{~A}$ & 3.05 & 1.13 & A \\
\hline 13 & $\begin{array}{l}\text { Not making a periodic assessment of what the } \\
\text { teacher is teaching in the school. }\end{array}$ & 2.60 & 1.12 & & A & 2.58 & 0.92 & A \\
\hline 14 & $\begin{array}{l}\text { Supervisors do not create time to ascertain whether } \\
\text { what has been taught is in line with the syllabus. }\end{array}$ & 2.87 & 1.18 & & A & 2.81 & 1.10 & A \\
\hline 15 & $\begin{array}{l}\text { Lack of adequate school supervisors and inspectors } \\
\text { at ministry of education PPSMB }\end{array}$ & 2.73 & 0.73 & & A & 2.80 & 1.05 & A \\
\hline 16 & $\begin{array}{l}\text { Lack of adequate material resource to carryout } \\
\text { proper supervision. }\end{array}$ & 2.95 & 1.14 & & A & 2.67 & 0.87 & A \\
\hline 17 & $\begin{array}{l}\text { Schools in the remote areas are not accessible to } \\
\text { supervisors. }\end{array}$ & 2.90 & 1.70 & & A & 2.69 & 1.13 & A \\
\hline \multirow[t]{2}{*}{18} & $\begin{array}{l}\text { Supervisors not liaising with the trained quality } \\
\text { assurance officers to learn how to use the handbook } \\
\text { during supervision. }\end{array}$ & 2.82 & 0.97 & & A & 2.88 & 0.93 & A \\
\hline & Grand mean & 2.84 & 0.97 & & A & 2.80 & 1.02 & A \\
\hline
\end{tabular}

Result on table 2 shows a grand mean of 2.84 for external supervisors and 2.80 for (principals) internal supervisors. The two grand mean were above the 2.50 benchmark. The result revealed that the respondents agreed that all the factors were hindering the utilization of Quality Assurance Handbook as guideline for supervision of instruction in the secondary school in Enugu State.

Research Hypothesis 1

Ho1 The difference in the mean scores of external and internal supervisors on the extent of utilization of the Quality Assurance Handbook is not statistically significant.

Table 3. t-test Statistical Analysis on the Response of External and Internal Supervisors on the Extent of Utilization of the Quality Assurance Handbook

\begin{tabular}{llllllll}
\hline Variables & Total & Mean & SD & DF & T-crit & T-cal & Decision \\
\hline External Sup & 60 & 2.48 & 1.09 & 208 & & \multirow{2}{*}{ \pm 1.96} & \multirow{2}{*}{ Uphold $\mathrm{H}_{01}$} \\
Internal Sup & 150 & 2.39 & 1.04 & & & & \\
\hline
\end{tabular}

$\mathrm{t}-\mathrm{cal}=\frac{\mathrm{X}_{1}-\mathrm{X}_{2}}{\sqrt{\frac{S^{1}}{n_{1}}+\frac{s^{2}}{n_{2}}}}$

$=\frac{2.48-2.39}{\sqrt{\frac{1.09^{2}}{60}+\frac{1.04^{2}}{150}}}$

$=\frac{0.09}{\sqrt{0.0198+0.00721}}$

$=0.548$

Table 3 revealed that calculated t-test value of 0.54 was less than the critical t-test value of \pm 1.96 at 0.05 level of significance and 208 degree of freedom. This has shown that the null hypothesis is upheld. From the result above, there is no significant different in the response of external and (principals) internal supervisors on the extent of utilization of Quality Assurance Handbook for supervision of instruction. 
Research Hypothesis 2

Ho2: There is no significant difference in the mean scores of external and internal supervisors on the challenges hindering the utilization of the Quality Assurance Handbook for supervision of instruction.

Table 4. t-test Statistical Analysis on the Mean Responses of External and Internal Supervisors on the Challenges Hindering the Utilization of the Quality Assurance Handbook in the Supervision of Instruction

\begin{tabular}{llllllll}
\hline Variables & Total & Mean & SD & DF & T-crit & T-cal & Decision \\
\hline External Sup & 60 & 2.48 & 0.97 & 208 & & \multirow{2}{*}{0.27} & Uphold $\mathrm{H}_{02}$ \\
Principal & 150 & 2.80 & 1.02 & & & & \\
\hline
\end{tabular}

$\mathrm{P}<.5 \quad$ NS Not significant.

$\mathrm{t}-\mathrm{cal}=\frac{\mathrm{X}_{1}-\mathrm{X}_{2}}{\sqrt{\frac{s^{1}}{n_{1}}+\frac{s^{2}}{n_{2}}}}$

$=\frac{2.48-2.80}{\sqrt{\frac{0.97^{2}}{60}+\frac{1.02^{2}}{150}}} \quad=\frac{0.04}{\sqrt{0.01568+0.006936}}$

$=0.27$

Table 4 above revealed that calculated t-test value is 0.27 is less than t-critical test value of \pm 1.96 at 0.05 level of significance and 208 degree of freedom. Therefore, the null hypothesis is not rejected. This shows that there is no significant difference in the mean score of principals on the factors hindering the utilization of Quality Assurance Handbook for supervision of instruction. Both categories of respondent experience almost the same challenges.

Only item 2 with mean 2.87 and 2.77 for both sides and items 10 with mean 2.63 for external supervisors and item 8 with mean 2.58 for internal supervisors were above the benchmark which show that the respondents agreed to an extent that the Quality Assurance Handbook were utilized regarding to these items.

\section{Discussion of Finding}

The result in table 1 revealed that both the external and internal supervisors (principals) do not make use of the Quality Assurance Handbook when performing their supervisory roles. This is because they do not ensure that quality is maintained at the course of performing, they do not undertake quality assurance external evaluation of schools on a regular basis and they do not use the comprehensive quality assurance document which contain information on valuation schedule and all other set standard as stipulated in the book. According to Federal Ministry of Education (2010) declared that education quality assurance in Nigeria is a paradigm shift from the former practices of school supervision and inspection to a monitory and evaluating process that provides of new operative mode of evaluation .

Regarding Research Question 2 which sought to identify the challenges facing principals and external supervisors in public secondary schools in the utilization of Quality Assurance Handbook. The findings in table 2 revealed that both external supervisors and principals agreed that all the items are militating factors judging from their grand mean of 2.84 and 2.80 respectively. There is the problem of unavailability of the Handbook in the schools, supervisors not being aware of the Handbook and non availability of adequate materials for supervision. This is in consonance with the opinion of Apebende (2013) and Wanzare (2012) supported the above that the problem frustrating practices of instructional supervision were lack of resources. While Akinloye and Olaoye (2014) attributed the problem to financial constraints.

There is the problem of supervisors not trained adequately in line with Quality Assurance Guideline. This will make them capable of carrying out their supervising duties.

The t-test analysis in table 3 and 4 revealed that there are no significant differences between the mean scores of external and internal supervisors on the utilization of Quality Assurance Handbook and at the same time, the challenges facing the two categories of supervisors are not statistically significant. 


\section{Conclusion and Recommendation}

The study identified the extent of utilization of Quality Assurance Handbook in the supervision of instruction and the factors hindering the utilization of the Handbook. The findings of the study revealed that it is not adequately utilized and a lot of factors hinder the use of it. These findings have a lot of implications for education in Enugu State because if the supervisors abide by the set standard in the book, teachers will achieve effective teaching and learning and learners in turn will achieve highly.

Based on the findings of the study, the following recommendations were made:

1. The Quality Assurance Handbook should be provided for all schools in the state for the principals to use during the supervision.

2. All supervisors both internal and external should be trained on all the set standard in the Handbook.

3. Supervisors should visit the schools regularly irrespective of the distance.

4. Materials needed for supervision should be provided by the government.

\section{References}

Abebe, T. (2014). The Practices and Challenges of School-Based Supervision in Government Secondary Schools in Kamashi Zone of Benishangul Crumuz Regional State. Thesis Submitted to the Department of Educational Planning and Management in Partial Fulfilment for the Requirement of Matters Degree in Jimma University.

Adu, E.O., Akinloye G.M., \& Olaoye, O.F. (2014). Internal and External School Supervision: Issues Challenges and Way Forward International Journal of Education Science, 7(2), 269-278.

Anton D. O., \& Naidoo J. P. (2004). UNESCO Seminar Report: School Evaluation for Quality Improvement: Issues and Challenges. Retrieved from http://www.unesco.org/iiep

Apebende E.U. (2013). Reforms and Innovation of the Primary Education in Nigeria System in Nigeria. Kano West and Solomon Publishing Co. Ltd.

Arong, F.E., \& Ogbadu, M.A. (2010). Major Causes of Declining Quality of Education in Nigeria from Administration Perspective: A Case Study of Dekina Local Government Area. Canadian Social Science, 6(3), 183-198.

Campbell, C., \& Rozsnyai, C. (2002). Quality assurance and the development of course programmes. Paper on higher education regional University network on governance on management of higher education in South East Europe, Bucharest, UNESCO.

Duff, T.H.J., \& Hussey, M. (2000). Academic quality assurance in Irish higher education: elements Elements of a handbook. Dublin. Blackhall XV.

Ekundayo, H.T., Oyerinde, D.O., \& Kolawole A.O. (2013). Effective Supervision of Instruction in Nigeria Secondary Schools: Issues, Challenges and the way Forward. Journal of Education and Practice, 4(8), 185-190.

Ekwukoma, V., \& Ohaeri, J.O. (2016). Taxonomy of unethical practices among university students and quality assurance. (Unpublished Journal Article).

ESS Quality Glossary (2010). Developed by Unit B1@Quality; Classifications Eurostat, 2010.

Federal Ministry of Education (2010). Education Quality Assurance Handbook for basic and secondary education in Nigeria. Nigeria.

Kotirde, I.Y., \& Yunos, J.B. (2014). The Supervisor's role for Improving the Quality of Teaching and Learning in Nigeria Secondary School Education system International Journal of Education and Research, 2(8), 53-60.

Ukwungwu, J.O. (2008). Quality assurance in junior school education: Gender consideration of serving teachers in Niger state. Journal of curriculum studies, 15(4), 161-171.

Wanzare Z.O. (2013). Skills and Attributed of Instructional Supervisors: Experience from Kenya. Educational Research and Reviews, 8(24), 2270-2280. 